\title{
Front Matter: Volume 6791
}

, "Front Matter: Volume 6791," Proc. SPIE 6791, Saratov Fall Meeting 2007: Optical Technologies in Biophysics and Medicine IX, 679101 (9 June 2008); doi: $10.1117 / 12.804486$

SPIE Event: Saratov Fall Meeting 2007: Optical Technologies in Biophysics and Medicine IX, 2006, Saratov, Russian Federation 


\section{PROGRESS IN BIOMEDICAL OPTICS AND IMAGING}

Vol. 9, No. 39

\section{Saratov Fall Meeting 2007}

\section{Optical Technologies in Biophysics and Medicine IX}

\section{Valery V. Tuchin}

Editor

\section{5-28 September 2007 \\ Saratov, Russia}

Organized by

Saratov State University (Russia) • Research-Educational Institute of Optics \& Biophotonics at SSU (Russia) • Institute of Precision Mechanics \& Control, RAS (Russia) • Research-Educational Center of Nonlinear Dynamics and Biophysics of CRDF and Ministry of Education and Science RF (REC-006) (Russia) • International Research-Educational Center of Optical Technologies for Industry and Medicine "Photonics" at SSU, National Russian Program of Innovative Universities (Russia) • Volga Regional Center of New Information Technologies (Russia)• Saratov Railway Clinic Hospital (Russia)

\section{In Cooperation with}

Russian Academy of Natural Sciences, Saratov Regional Division • Russian Society for Photobiology • Saratov Science Center of the Russian Academy of Sciences

Sponsored by

Russian Foundation for Basic Research • SPIE Russia Chapter • Saratov State University SPIE Student Chapter - U.S. Civilian Research and Development Foundation for the Independent States of the Former Soviet Union (CRDF) • Russian Academy of Sciences • British Council, Program British Degrees in Russia • SPE "Nanostructed Glass Technology" Ltd. • SPE "Erudit" Ltd.

Published by

SPIE

Volume 6791 
The papers included in this volume were part of the technical conference cited on the cover and title page. Papers were selected and subject to review by the editors and conference program committee. Some conference presentations may not be available for publication. The papers published in these proceedings reflect the work and thoughts of the authors and are published herein as submitted. The publisher is not responsible for the validity of the information or for any outcomes resulting from reliance thereon.

Please use the following format to cite material from this book:

Author(s), "Title of Paper," in Saratov Fall Meeting 2007: Optical Technologies in Biophysics and Medicine IX, edited by Valery V. Tuchin, Proceedings of SPIE Vol. 6791 (SPIE, Bellingham, WA, 2008) Article CID Number.

ISSN 1605-7422

ISBN 9780819469557

Published by

SPIE

P.O. Box 10, Bellingham, Washington 98227-0010 USA

Telephone +1 3606763290 (Pacific Time) · Fax +1 3606471445

SPIE.org

Copyright (C) 2008, Society of Photo-Optical Instrumentation Engineers.

Copying of material in this book for internal or personal use, or for the internal or personal use of specific clients, beyond the fair use provisions granted by the U.S. Copyright Law is authorized by SPIE subject to payment of copying fees. The Transactional Reporting Service base fee for this volume is $\$ 18.00$ per article (or portion thereof), which should be paid directly to the Copyright Clearance Center (CCC), 222 Rosewood Drive, Danvers, MA 01923. Payment may also be made electronically through CCC Online at copyright.com. Other copying for republication, resale, advertising or promotion, or any form of systematic or multiple reproduction of any material in this book is prohibited except with permission in writing from the publisher. The CCC fee code is 1605 $7422 / 08 / \$ 18.00$.

Printed in the United States of America.

Publication of record for individual papers is online in the SPIE Digital Library.

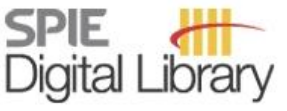

SPIEDigitallibrary.org

Paper Numbering: Proceedings of SPIE follow an e-First publication model, with papers published first online and then in print and on CD-ROM. Papers are published as they are submitted and meet publication criteria. A unique, consistent, permanent citation identifier (CID) number is assigned to each article at the time of the first publication. Utilization of CIDs allows articles to be fully citable as soon they are published online, and connects the same identifier to all online, print, and electronic versions of the publication. SPIE uses a six-digit CID article numbering system in which:

- The first four digits correspond to the SPIE volume number.

- The last two digits indicate publication order within the volume using a Base 36 numbering system employing both numerals and letters. These two-number sets start with 00, 01, 02, 03, 04 , 05, 06, 07, 08, 09, 0A, OB ... 0Z, followed by 10-1Z, 20-2Z, etc.

The CID number appears on each page of the manuscript. The complete citation is used on the first page, and an abbreviated version on subsequent pages. Numbers in the index correspond to the last two digits of the six-digit CID number. 


\section{Contents}

vii Saratov Fall Meeting 2007 Committees

xi Introduction

\section{SESSION $1 \quad$ PLENARY LECTURES}

679102 Optimized microviscosimeter using optical probing: application to biological membranes [6791-01]

B. Cretin, O. Gaiffe, W. Boireau, P. Vairac, Femto-ST Institute, Univ. de Franche-Comté, CNRS, ENSMM, UTBM (France)

679103 International Research-Educational Center of Optical Technologies for Industry and Medicine "Photonics" at Saratov State University: education, research, and commercialization [6791-02]

V. V. Tuchin, Saratov State Univ. (Russia) and Institute of Precise Mechanics and Control (Russia)

\section{SESSION 2 SELECTED INVITED LECTURES}

679104 Fluorescence detection of esophageal neoplasia [6791-03]

E. Borisova, Institute of Electronics (Bulgaria); B. Vladimirov, Univ. Hospital Queen Jovanna (Bulgaria); L. Avramov, Institute of Electronics (Bulgaria) and Optella Ltd. (Bulgaria)

679105 Cutaneous tumors in vivo investigations using fluorescence and diffuse reflectance techniques [6791-04] E. Borisova, Institute of Electronics (Bulgaria); P. Troyanova, E. Nikolova, National Oncological Diagnostic Ctr. (Bulgaria); L. Avramov, Institute of Electronics (Bulgaria)

679106 Features of cross-polarization imaging [6791-05]

V. M. Gelikonov, Institute of Applied Physics (Russia)

679107 The effect of solution concentration on diffusion in scleral tissues [6791-06] M. G. Ghosn, E. F. Carbajal, N. A. Befrui, Univ. of Houston (USA); V. V. Tuchin, Saratov State Univ. (Russia) and Institute of Precise Mechanics and Control (Russia); K. V. Larin, Univ. of Houston (USA) and Saratov State Univ. (Russia)

679108 Induced uniaxial optical activity of hemoglobin solutions in constant magnetic field [6791-07]

O. V. Ivanov, Institute of Radio Engineering and Electronics (Russia); A. M. Shuty, Ulyanovsk State Univ. (Russia)

679109 Tooth study by terahertz time-domain spectroscopy [6791-08]

M. M. Nazarov, A. P. Shkurinov, M.V. Lomonosov Moscow State Univ. (Russia); V. V. Tuchin, Saratov State Univ. (Russia) and Institute of Precise Mechanics and Control (Russia) 
6791 OA Ultra-sensitive monitoring of analyte concentrations using phase sensitive spectral domain OCT [6791-09]

V. G. R. Manne, R. K. Manapuram, N. Sudheendran, Univ. of Houston (USA); K. V. Larin, Univ. of Houston (USA) and Saratov State Univ. (Russia)

\section{SESSION 3 INTERNET INVITED LECTURES}

6791 OB Benefits in clinical dermatology from methodological and technological innovations in laser and optical technologies in inter-and multi-disciplinary research [6791-10] N. S. Eikje, Waseda Univ. (Japan)

$67910 C$ Quenching of fluorescence by crystal violet and its use to differentiate between surfacebound and internalized bacteria [6791-11]

S. Mathew, Y. C. Lim, A. Kishen, Faculty of Medicine, National Univ. of Singapore (Singapore)

6791 OD Generalized differential Mueller matrix for homogeneous anisotropic media [6791-12] S. N. Savenkov, I. S. Marfin, Kiev Taras Shevchenko Univ. (Ukraine)

6791 OE Optical phase contrast microscope imaging: a FDTD modeling approach [6791-13] S. Tanev, Carleton Univ. (Canada); J. Pond, P. Paddon, Lumerical Solutions, Inc. (Canada); V. V. Tuchin, Saratov State Univ. (Russia) and Institute of Precise Mechanics and Control (Russia)

6791 OF Skin optical clearing enhancement with penetration enhancer azone using spectroscopy and optical coherence tomography [6791-14]

X. XU, Q. Zhu, Zhejiang Sci-Tech Univ. (China)

6791 OG Optical monitoring of rheumatoid arthritis: Monte Carlo generated reconstruction kernels [6791-15]

O. Minet, J. Beuthan, Charité Universitätsmedizin Berlin, Institut für Medizinische Physik und Laser Medizin (Germany); A. H. Hielscher, Columbia Univ. (USA); U. Zabarylo, Charité Universitätsmedizin Berlin, Institut für Medizinische Physik und Laser Medizin (Germany)

$6791 \mathrm{OH} \quad$ Investigation of tissue oxygenation by in vivo laser-induced photodissociation of cutaneous arterial blood oxyhemoglobin [6791-16]

M. M. Asimov, Institute of Physics (Belarus); A. N. Korolevich, Belarusian Institute of System Analysis and Information Support of Scientific Technical Sphere (Belarus)

6791 ol Tunable trans-illumination interferometer and tuned-state identification based on recurrence analysis [6791-17]

P. Vacas-Jacques, M. Strojnik, Ctr. de Investigaciones en Optica (Mexico)

6791 0J A simple mixture to enhance muscle transmittance [6791-18]

L. Oliveira, Ctr. de Ciências e Tecnologias Ópticas (Portugal); A. Lage, Porto Univ. (Portugal); M. P. Clemente, Ctr. de Ciências e Tecnologias Ópticas (Portugal); V. V. Tuchin, Saratov State Univ. (Russia) 
6791 OK The registration of flow of erythrocytes and their complexes in vitro by means of crosscorrelation technique [6791-19]

Y. A. Ganilova, V. A. Dubrovskiy, Saratov State Medical Univ. (Russia); S. S. Uliyanov, Saratov State Univ. (Russia)

6791 OL Improved stereoscopic imagery in Greenough stereomicroscope: correction for vertical imbalance [6791-20]

K. A. Grebenyuk, V. V. Petrov, Saratov State Univ. (Russia)

6791 OM Development of a mount classifier based on the invariant Zernike moments method [6791-21]

I. L. Maksimova, A. S. Ulyanov, Saratov State Univ. (Russia)

6791 ON The changes of stimulated Raman scattering spectrum of ceruloplasmin by powerful laser radiation [6791-22]

E. A. Il'ina, S. A. Kutsenko, I. N. Ulchenko, Volgograd State Univ. (Russia)

SESSION 6 SPECTROSCOPY

679100 Measurements of absorbance of hemoglobin solutions incubated with glucose [6791-23]

E. N. Lazareva, Saratov State Univ. (Russia); V. V. Tuchin, Institute of Precise Mechanics and Control (Russia); I. V. Meglinski, Saratov State Univ. (Russia) and Cranfield Univ. (United Kingdom)

6791 OP The luminescence of polycyclic aromatic hydrocarbons on modified by surface-active agent cellulose [6791-24]

O. A. Djachuk, A. V. Tkachenko, Saratov State Technical Univ. (Russia)

\section{SESSION 7 OPTICAL AND CLINICAL BIOPHYSICS}

$67910 Q$ Optimization of laser heating with the treatment of spontaneous tumors of domestic animals by use of thermography [6791-25]

G. S. Terentyuk, First Veterinary Clinic (Russia); G. G. Akchurin, I. L. Maksimova, Saratov State Univ. (Russia); G. N. Maslyakova, L. V. Suleymanova, Saratov Medical State Univ. (Russia); V. V. Tuchin, Saratov State Univ. (Russia) and Institute of Precise Mechanics and Control (Russia)

6791 OR In vitro LED and laser light photoinactivation of Propionibacterium acnes [6791-26]

E. S. Tuchina, V. V. Tuchin, Saratov State Univ. (Russia)

6791 OS The effect of Escherichia coli toxins on blood microcirculation in ventral mesentery of white rats [6791-27]

D. V. Podschibyakin, S. S. Ulyanov, Saratov State Univ. (Russia); O. V. Ulianova, Saratov State Agrarian Univ. (Russia) and Saratov State Univ. (Russia); E. I. Tikhomirova, M. A. Shibaeva, Saratov State Univ. (Russia) 
6791 OT Dentinal permeation modeling [6791-28]

N. Trunina, V. Derbov, V. Tuchin, Saratov State Univ. (Russia); G. Altshuler, St. Petersburg

State Univ. of Information Technology, Mechanics and Optics (Russia)

$67910 \mathrm{C}$ Comparative study of human hard tooth tissue removal efficiency by Er-laser pulses with different temporal structure [6791-29]

A. V. Belikov, A. V. Skripnik, E. P. Zholobova, St. Petersburg State Univ. of Information Technologies, Mechanics and Optics (Russia)

\section{SESSION 8 MANAGEMENT AND EDUCATION}

6791 OV Self-management and creativity [6791-30]

B. A. Medvedev, A. A. Skaptsov, M. A. Polikarpov, Saratov State Univ. (Russia)

6791 OW Organizational and economical aspects of telemedicine training in the Archangelsk region [6791-31]

A. N. Pankratov, K. K. Rogalev, Arkhangelsk Regional Clinical Hospital (Russia)

$67910 X \quad$ Formal letter writing [6791-33]

S. V. Eremina, O. I. Moskalenko, Sarataov State Univ. (Russia)

Internet Lecture Discussion

Author Index 


\section{Saratov Fall Meeting 2007 Committees}

\section{Annual International Multidisciplinary School for Young Scientists and Students on Optics, Laser Physics and Biophysics XI: Saratov Fall Meeting 2007}

Valery V. Tuchin, Chair, Saratov State University (Russia) and Institute of Precision Mechanics and Control, RAS (Russia)

Elina A. Genina, Secretary, Saratov State University (Russia)

\section{General Program Committee}

Lev M. Babkov, Saratov State University (Russia)

Valentin I. Berezin, Saratov State University (Russia)

Michael V. Davidovich, Saratov State University (Russia)

Vladimir L. Derbov, Saratov State University (Russia)

Svetlana V. Eremina, Saratov State University (Russia)

Nikolai G. Khlebtsov, Institute of Biochemistry and Physiology of Plants and Microorganisms, RAS (Russia)

Vyacheslav I. Kochubey, Saratov State University (Russia)

Leonid A. Melnikov, Saratov State University (Russia)

Alexander B. Pravdin, Saratov State University (Russia)

Vladimir P. Ryabukho, Saratov State University (Russia) and Institute of Precision Mechanics and Control, RAS (Russia)

Alexander M. Sergeev, Institute of Applied Physics, RAS (Russia)

Sergey N. Shtykov, Saratov State University (Russia)

Valery V. Tuchin, Saratov State University (Russia) and Institute of Precision Mechanics and Control, RAS (Russia)

Dmitry A. Zimnyakov, Saratov State University (Russia) and Institute of Precision Mechanics and Control, RAS (Russia)

\section{General Organizing Committee}

Dmitry A. Zimnyakov, Chair, Saratov State University (Russia) and Institute of Precision Mechanics and Control, RAS (Russia)

Members

Garif G. Akchurin, Saratov State University (Russia) and Institute of Precision Mechanics and Control, RAS (Russia) 
Alexander G. Akchurin, Saratov State University (Russia)

Edmund I. Akopov, SPIE Russia Chapter (Russia)

Alexey N. Bashkatov, Saratov State University (Russia)

Kirill V. Berezin, Saratov State University (Russia)

Anna A. Gavrilova, Saratov State University (Russia)

Elina A. Genina, Saratov State University (Russia)

Alexander L. Kalyanov, Saratov State University (Russia)

Andrey I. Konyukhov, Saratov State University (Russia)

Liana Kuznetsova, Saratov State University (Russia)

Nina A. Lakodina, Saratov State University (Russia)

Ekaterina Lazareva, Saratov State University (Russia)

Vladislav V. Lychagov, Saratov State University (Russia)

Igor V. Meglinsky, Cranfield University (United Kingdom) and Saratov State University (Russia)

Olga A. Perepelitsina, Saratov State University (Russia) and Institute of Precision Mechanics and Control, RAS (Russia)

Georgy V. Simonenko, Saratov State University (Russia)

Maxim A. Vilensky, Saratov State University (Russia)

Irina Yu. Yanina, Saratov State University (Russia)

Olga Zhernovaya, Saratov State University (Russia)

\section{Internet Group}

Dmitry A. Agafonov, Cochair, Saratov State University (Russia)

Ivan V. Fedosov, Cochair, Saratov State University (Russia)

Members

Georgy V. Simonenko, Saratov State University (Russia)

Andrey Spivak, Saratov State University (Russia) 


\section{Workshop on Optical Technologies in Biophysics and Medicine IX}

Valery V. Tuchin, Workshop Chair, Saratov State University (Russia) and Institute of Precision Mechanics and Control, RAS (Russia)

Elina A. Genina, Secretary, Saratov State University (Russia)

\section{International Program Committee}

Victor N. Bagratashvili, Institute of Laser and Information Technologies, RAN

(Russia)

Gregory E. Brill, Saratov State Medical University (Russia)

Britton Chance, University of Pennsylvania (USA)

Wei Chen, University of Central Oklahoma (USA)

Paul M. W. French, Imperial College of Science, Technology and Medicine (United Kingdom)

James G. Fujimoto, Massachusetts Institute of Technology (USA)

Christoph K. Hitzenberger, University of Vienna (Austria)

Joseph A. Izatt, Case Western Reserve University (USA)

Steven L. Jacques, Oregon Health and Sciences University (USA)

Sean J. Kirkpatrick, Oregon Health and Sciences University (USA)

Juergen Lademann, Humboldt University (Germany)

Igor V. Meglinsky, Cranfield University (United Kingdom) and Saratov State University (Russia)

Qingming Luo, Huazhong University of Science and Technology (China)

Risto Myllylä, University of Oulu (Finland)

Theodore G. Papazoglou, FORTH-IESL (Greece)

Alexander V. Priezzhev, Lomonosov Moscow State University (Russia)

Lihong Wang, Texas A\&M University (USA)

Ruikang K. Wang, Oregon Health and Sciences University (USA)

Dmitry A. Zimnyakov, Saratov State University (Russia) and Institute of Precision

Mechanics and Control, RAS (Russia)

Session Chairs

Plenary Session I

Valery V. Tuchin, Saratov State University (Russia) and Institute of Precision Mechanics and Control, RAS (Russia)

Plenary Session II

Alexander V. Priezzhev, Lomonosov Moscow State University (Russia)

Plenary Session III

Igor Nefedov, University of Helsinki (Finland) 
Plenary Session IV

Michael Whitcombe, Cranfield University (United Kingdom)

Plenary Session V

Stephen J. Matcher, University of Sheffield (United Kingdom)

Plenary Session VI

Bernard Cretin, FEMTO-ST Institute (France)

Plenary Session VII

Igor Meglinski, Cranfield University (United Kingdom)

Lecture Session I

Alexander V. Priezzhev, Lomonosov Moscow State University (Russia)

Lecture Session II

Anna N. Yaroslavsky, Harvard Medical School (USA)

Lecture Session III/Oral Session I

Mikhail Kirilin, Lomonosov Moscow State University (Russia)

Oral Session II

Kirill Larin, University of Houston (USA)

Oral Session III

Ivan V. Fedosov, Saratov State University (Russia)

Oral Session IV: Workshop on Management of High Technologies Commercialization IV

Yuliya S. Skibina, Saratov State University (Russia)

Yuri P. Sinichkin, Saratov State University (Russia)

Vladimir P. Ryabukho, Saratov State University (Russia)

Oral Session V: Seminar on Telemedicine: Opportunities, Applications, Prospects II

Irina L. Maksimova, Saratov State University (Russia)

Elena V. Karchenova, Saratov Railway Clinical Hospital (Russia)

Poster Session

Alexander G. Akchurin, Saratov State University (Russia)

Dmitry Lyakin, Institute of Precision Mechanics and Control, RAS (Russia)

Internet Plenary Session

Alexander V. Priezzhev, Lomonosov Moscow State University (Russia)

Valery V. Tuchin, Saratov State University (Russia) and Institute of

Precision Mechanics and Control, RAS (Russia)

Discussion via Internet

Alexander V. Priezzhev, Lomonosov Moscow State University (Russia) 


\section{Introduction}

The Annual International Multidisciplinary School for Young Scientists and Students on Optics, Laser Physics and Biophysics XI (Saratov Fall Meeting (SFM-07)) was held in Saratov, Russia, 25-28 September, 2007 with about 600 participants from Russia, FSU countries, USA, Canada, Europe, and Asia. The meeting covered a wide range of modern problems in fundamental and applied optics, laser physics, photonics, and biomedical optics.

SFM-07 also contained 11 International Workshops and Seminars:

- Optical Technologies in Biophysics and Medicine IX (Valery V. Tuchin, Chair)

- Coherent Optics of Ordered and Random Media VIII (Dmitry A. Zimnykov, Chair)

- Laser Physics and Photonics IX (Leonid A. Melnikov and Vladimir L. Derbov, Chairs)

- Spectroscopy and Molecular Modeling VIII (Valentin I. Berezin, Lev M. Babkov, and Michael D. Elkin, Chairs)

- Electromagnetics of Microwaves, Submillimeter and Optical Waves $V$ (Michael V. Davidovich, Chair)

- English as a Communicative Tool in the Scientific Community V (Vladimir L. Derbov, Svetlana V. Eremina, and Alexander B. Pravdin, Chairs)

- Management of High Technologies Commercialization and Regional Innovation Systems IV (Valery V. Tuchin, Chair)

- Luminescence III (Vyacheslav I. Kochubey and Sergey N. Shtykov, Chairs)

- Nanostructures and Nanoparticles: Fabrication, Properties, and Applications III (Nikolai G. Khlebtsov, Chair)

- Telemedicine: Opportunities, Applications, Prospects II (Irina L. Maksimova, Elena V. Karchenova, Chairs)

- Modern Optics for Secondary School VI (Vladimir P. Ryabukho, Chair)

The main organizers of the Saratov Fall Meeting 2007 were Saratov State University (SSU), Research-Educational Institute of Optics and Biophotonics at SSU, Institute of Precision Mechanics and Control of the Russian Academy of Sciences, Research-Educational Center of Nonlinear Dynamics and Biophysics of CRDF and Ministry of Education and Science RF (REC-006), and International ResearchEducational Center of Optical Technologies for Industry and Medicine "Photonics" at SSU, National Russian Program of Innovative Universities.

The main goal of the School, Workshops, and Seminars is to involve young researches and students in the field of recent developments and applications of laser and optical technologies in medicine and biology, coherent optics of random and ordered media, material and environmental sciences, nonlinear dynamics of laser systems, laser spectroscopy, and molecular modeling. A main focus was on the discussion of fundamentals and general approaches to 
description of coherent, low-coherent, polarized, spatially and temporally modulated light interactions with inhomogeneous absorbing media, photonic crystals, tissue phantoms, and various types of tissues in vitro and in vivo. Such effects as static and dynamic light scattering, Doppler, optoacoustic and optothermal interactions, mechanical stress, photodynamic effect, etc. were considered. A variety of laser and optical technologies for medical diagnostics, therapy, surgery, and light dosimetry, as well as for spectroscopy of random and ordered media were presented.

SFM-07 was organized with morning plenary sessions, afternoon lecture and oral sessions, and evening poster presentations. The original oral reports and posters were presented by junior scientists and students. Plenary lectures were received with great interest and were followed by discussion from the audience.

Plenary and invited lectures, and oral and poster presentations covered a wide range of tissue optics, spectroscopy and imaging, controlling of optical properties of tissues, as well as biophysical and photo-chemical aspects of photo and laser therapy. Outside this SPIE proceedings volume, a few special issues and sections will be published in well-recognized peer-reviewed journals, such as Quantum Electronics, Journal of Applied Nonlinear Dynamics, and Physical series of News of Saratov University.

An SPIE short course for students, engineers, scientists, and clinicians, "The effects of tissue on light - an introduction to optical diagnostics in medicine," by Dr. Alex Vitkin, University of Toronto, Canada, accompanied the conference. The course had more than 30 attendees, mostly students, and was organized by Saratov State University SPIE Student Chapter, and was supported by SPIE and Saratov State University.

A unique element of the Saratov Fall Meetings is its one-day Internet Session. In 2007 this session included the following plenary lectures: "High-resolution photoacoustic tomography" by Lihong V. Wang, Washington University in St. Louis, St. Louis, USA; "New generation ultrathin all-fiber-optic endomicroscopy and molecular bio-nanophotonics" by Xingde Li, Department of Bioengineering, University of Washington, Seattle, USA; and "A new light on the biosciences" by Kishan Dholakia, School of Physics and Astronomy, University of St. Andrews, St. Andrews, United Kingdom.

Participants from USA, Russia, Austria, Australia, Bulgaria, Canada, Finland, Germany, Ireland, United Kingdom, Slovakia, Canada, China, Portugal, Italy, Japan, Ukraine, Belarus, Switzerland, Denmark, Spain, Singapore, the Netherlands, Poland, India, and other countries have posted their papers on the meeting website: http://optics.sgu.ru/SFM/, which was available during the meeting and will be available for an entire year until the next meeting. A three-hour on-line Internet discussion of all the Internet Session papers was moderated by Alexander Priezzhev. One of the Internet papers is published in this proceedings volume. 
The majority of the papers in this volume include papers presented on the Workshop "Optical Technologies in Biophysics and Medicine IX" However, a few papers presented in the Workshops "Management of High Technologies Commercialization IV" and "Telemedicine: Opportunities, Applications, Prospects II" are also published in the volume. A great number of the presented papers were the results of collaborations between research groups from different countries, supported by international scientific programs such as CRDF, INTAS, Royal Society, and others.

This is a great pleasure and privilege for me to thank all of the authors for their contributions to SFM-07, especially the Internet lecturers for their exciting presentations. Great thanks go to Alexander Priezzhev, who has contributed his talent and impressive moderation to the Internet Sessions for the last ten years.

The organizers of SFM-07 are grateful to all of the sponsoring organizations and programs that supported this meeting very effectively, especially to: SPIE; Russian Foundation for Basic Research; U.S. Civilian Research \& Development Foundation for the Independent States of the Former Soviet Union (CRDF), grant REC-006 and mini-grant for Conference support; and Volga Region Center of New Information Technologies.

I would like to thank SPIE Student Services for their support of the Conference education program, and Elina Genina and Ivan Fedosov for their help in preparation of the manuscripts.

Valery V. Tuchin 
Downloaded From: https://www.spiedigitallibrary.org/conference-proceedings-of-spie on 26 Apr 2023

Terms of Use: https://www.spiedigitallibrary.org/terms-of-use 